$1-1-2012$

\title{
Price Dispersion In The Airline Industry: A Conceptual Framework And Empirical Analysis
}

\author{
Edward D. Gailey \\ Ashutosh Dixit \\ Cleveland State University, a.dixit1@csuohio.edu \\ Thomas W. Whipple \\ Cleveland State University, t.whipple@csuohio.edu \\ Rajshekar G. Javalgi \\ Cleveland State University, r.javalgi@csuohio.edu
}

Follow this and additional works at: https://engagedscholarship.csuohio.edu/bus_facpub

Part of the Marketing Commons

How does access to this work benefit you? Let us know!

\section{Publisher's Statement}

This article was originally published in the American Journal of Management. http://www.nabusinesspress.com/ajmopen.html

\section{Original Published Citation}

Gailey, E.D., Dixit, A., Whipple, T.W., \& Javalgi, R. (2012). Price dispersion in the airline industry: A conceptual framework and empirical analysis. American Journal of Management, 12(1), 92-107.

This Article is brought to you for free and open access by the Monte Ahuja College of Business at EngagedScholarship@CSU. It has been accepted for inclusion in Business Faculty Publications by an authorized administrator of EngagedScholarship@CSU. For more information, please contact library.es@csuohio.edu. 


\title{
Price Dispersion in the Airline Industry: A Conceptual Framework and Empirical Analysis
}

\author{
Edward D. Gailey \\ Fairmont State University \\ Ashutosh Dixit
Cleveland State University \\ Thomas W. Whipple \\ Cleveland State University \\ Rajshekhar 'Raj' Javalgi \\ Cleveland State University
}

\begin{abstract}
Many businesses compete in multiple markets which can cause businesses to temper their price adjustments, affecting price dispersion. The authors propose a framework based on major characteristics of competition and market structure which influence price dispersion. The focus of this study is the U.S. airline industry analyzing data from 5,974 city pair routes. The results of this empirical analysis show that multi-market contact and the interaction of market concentration with multi-market contact have considerable effects on price dispersion. An understanding of these effects provides valuable insights for developing pricing strategies and extending the stream of research on price dispersion.
\end{abstract}

\section{INTRODUCTION}

Businesses focus setting prices and adjusting prices to influence demand and profitability. In many service markets, such as airline tickets, hotel rooms, and entertainment venues, diverse prices are frequently offered by different businesses to cater to various market segments having particular sets of wants and needs. This variation in prices (i.e., price dispersion) is not only based on customer heterogeneity, but also on competition and market related characteristics. The effect of some important aspects of competition and market structure has been largely overlooked in extant research on price dispersion. Understanding the presence or absence of exploitable imperfections in markets and the implications for developing pricing strategies are critical for the long-term viability of businesses that must compete in environments with increasingly informed customers (Clemons, Hann, \& Hitt, 2002).

A pricing strategy is a rational selection from a range of possible prices targeted for meeting a firm's objectives planned to respond to a specific situation (Tellis, 1986). Effective pricing strategy is based on a thorough understanding of the target market including the nature and complexity of; products, consumers, competitors, and market structures (see Monroe, 2003; Nagle \& Holden, 2002). Recent advances in 
information technology, such as digital products, real time computational abilities, intelligent agent technologies, and database marketing, open a vast array of pricing strategy possibilities (Dixit, Whipple, Zinkham, \& Gailey, 2008).

This research seeks to provide understanding of how competitive forces and market characteristics influence price dispersion. Price dispersion impacts consumers' perceptions of value and purchase behavior which in turn affects sales revenue and profitability of firms and industries. Specifically, we focus on the following research questions in this study: 1. How does multi-market contact, the degree to which rival firms compete in different markets, affect price dispersion? 2. How does market concentration affect the relationship between multi-market contact and price dispersion? If the forces affecting price dispersion are better understood, managers may be able to develop enhanced business strategies and plans, leading to higher performance.

Price dispersion is the variation in prices of homogeneous products sold by competing firms (Stigler, 1961; Borenstein \& Rose, 1994; Zhao, 2006). Stigler's (1961) seminal article discusses the effect of the differences in customer search costs on price dispersion. Stigler states that price dispersion is ubiquitous even for homogeneous products. Stigler's conclusion is that price dispersion is caused by consumers' lack of information due to search costs and variation in 'terms of sale'.

Prior research findings indicate that markets for many homogeneous products are characterized by considerable price dispersion (e.g., Stigler, 1961; Pan, Ratchford, \& Shankar, 2004). Emerging streams of research suggest that specific types of market imperfections (e.g., Lindsey-Mullikin \& Grewal, 2006; Grewal \& Marmorstein, 1994), customer learning (e.g., Johnson, Moe, Fader, Bellman, \& Lohse, 2000), and brand loyalty (e.g., Chen \& Hitt, 2001) influence price dispersion. These scholars mainly focus on consumer related influences on price dispersion. The effects of multi-market contact, an important influence on competitive pressure and price dispersion, have not been studied.

Our study contributes to price dispersion research in several important ways. First, it provides a much needed conceptual framework of price dispersion in a complex, service market (i.e., airline ticket). Second, it empirically examines the influence of previously unexplored competition related variables, such as multi-market contact, and the interaction of market concentration on the effect that multi-market contact has on price dispersion. Third, it contributes managerial insight to decision makers in retail service industries.

\section{RELATED LITERATURE}

Scholars in marketing have investigated the effects of price dispersion on key marketing variables as well as the causes of price dispersion. A review of literature resulted in two major streams of research; (1) consumer heterogeneity (including search cost, customer learning, and brand loyalty) and (2) market structure and competition. A study by Anacarani and Shankar (2004) evaluates the influence of the Internet on price dispersion of books and music CDs across Internet-only retailers, traditional retailers, and multi-channel retailers. Their results show that multi-channel retailers have the most price dispersion, traditional retailers the second highest price dispersion, and Internet-only retailers the least price dispersion. These findings indicate that the online markets offer opportunities for retailers to differentiate prices within and across the retailer types, similar to traditional markets.

Biswas, Dutta, and Pullig (2006) studied the moderating role of perceived price dispersion on low price guarantees. Price dispersion is evaluated as a signal for lowest price in a retail environment using mock ads for a branded DVD player. The results show that price guarantee effects are attenuated when consumers perceive price dispersion to be high for a given product. The results also indicate that a low price guarantee with progressively higher levels of penalty leads incrementally to more favorable effects on key consumer outcomes when perceived price dispersion is high. The effect of increasing the penalty level had no such incremental benefit on consumer outcomes in the situation of low perceived price dispersion.

Zhao (2006) evaluated price dispersion in the grocery market and checked for the consistency of evidence of price dispersion with theories related to consumer heterogeneity, consumer search, and 
competition. Zhao applies these three influencers of price dispersion to evaluate price dispersion in three situations; (1) for a specific brand across stores, (2) within a product category in a store across brands, and (3) over time for a specific brand. Zhao's research shows price dispersion to positively correlate with consumer heterogeneity, consumer search, and competition, which is consistent with the theories related to price dispersion.

\section{CONCEPTUAL FRAMEWORK AND HYPOTHESES}

According to the 'law of one price' supply and demand determine a single price for a homogenous product, regardless of the number of sellers and buyers. In reality, it is well known by marketing scholars and economists that 'one price' rarely, if ever, occurs in real markets. Homogeneous products are often sold at widely differing prices by competing firms, even in markets that are highly competitive, such as the U.S. airline ticket market. This study examines key competitive and market factors that may influence price dispersion, and evaluates the consistency with theories. Specifically, it examines multi-market contact and the interaction with market concentration as influencers of price dispersion.

We present a conceptual framework in FIGURE 1 (See Appendix). As shown in the diagram, price dispersion is influenced by two groups of independent variables; one group of competition related characteristics and another group of local market related characteristics. This conceptual framework indicates the expected relationships between the independent variables and the dependent variable, price dispersion. In the following section we discuss each construct and derive hypotheses.

\section{Multi-Market Contact}

Prior literature has typically studied price dispersion in single markets, and has not examined the relationship between multi-market contact and price dispersion. Multi-market contact is defined as the level of competitive contact, which firms in an industry have in multiple markets (Bernheim \& Whinston, 1990; Karnani \& Wernerfelt, 1985; Evans \& Kessides, 1994; Baum \& Korn, 1996). For any pair of rivals in a market, multi-market contact represents the number of other markets in which the same pair of firms met as competitors. Thus, multi-market contact between two competing firms in a given market reflects the degree of market overlap between those firms in the other markets.

The theory of multi-market competition (Jayachandran, Gimeno, \& Varadarajan, 1999) implies that multi-market contact between two rival firms will reduce the intensity of rivalry between them in each market where they compete (Bernheim \& Whinston, 1990). Even though multi-market contact indicates that firms are competitors across sub-markets, the theory suggests that the intensity of rivalry in each of the mutually contested markets will be low. The reason for such an effect, according to the theory, is that firms with high multi-market contact have an extended scope for retaliation to actions taken by the rival because the possibility for cross-market retaliation is a likely possibility (Feinberg, 1984).

Although there are differing views on the influence that multi-market contact may have on competition, the conclusions of most research (e.g., Bernheim \& Whinston, 1990) supports the premise that as multi-market contact increases, intensity of rivalry will decrease. This decrease in competitive rivalry is expected to result in an increase in price dispersion due to firms feeling less pressure to match or be close to competitors' prices. The theoretical predictions are consistent with the rivalry-decreasing effect of multi-market contact on price dispersion and are represented in the following hypothesis:

\section{Hypothesis 1: The degree of multi-market contact among firms competing in a local market is positively related to price dispersion in the local market.}

\section{Market Concentration within a Local Market}

Prior studies have examined the relationship between market concentration and price dispersion in a market. Market concentration is the degree of dominance of firms selling similar products within a specific market. Greater concentration of market share increases the market power of the dominant firms, which in turn results in higher prices. In the extreme case of concentration, a single firm totally dominates 
the market (i.e., monopoly). The concept of greater market concentration leading to greater market power of dominant firms and resulting in higher prices, has been well documented and is one of the main justifications for the U.S. Government monitoring and limiting industry concentration.

Price dispersion has an inverted-U relationship with market concentration. In the case of the city-pair routes in this study, the relationship of price dispersion to market concentrations is on the side of the inverted-U where the relationship is negative; as concentration increases, price dispersion decreases.

Market concentration is typically measured by the Herfindahl index (also referred to as the Herfindahl-Hirshman index), which is the market share for each firm competing within a market, squared, and then summed. Market concentration is one of the independent variables applied by Borenstein and Rose, (1994); Hayes and Ross, (1998); and Zhao (2006) to evaluate the causes of price dispersion. All three of these studies find the expected result that price dispersion is inversely related to concentration. Simply stated, as a market becomes more concentrated, price dispersion tends to be reduced. In this study, the city-pair route is the sub-market of interest and therefore, concentration of airlines is calculated using the Herfindahl index methodology on each city-pair route. The following hypothesis reflects the expected inverse main effect relationship between market concentration (city-pair routes in this study) and price dispersion.

\section{Hypothesis 2: The degree of market concentration in a local market is negatively related to price dispersion in the local market.}

\section{Multi-Market Contact and Market Concentration Interaction}

In this study a major factor of interest is the interaction of multi-market contact, which can potentially affect oligopolistic coordination within specific markets, with market concentration. The effect of multimarket contact on price dispersion is expected to be moderated by market concentration (Jayachandran, Gimeno, \& Vanadarajan, 1999). The airline industry is an oligopoly and the local markets tend to exhibit a high degree of concentration. Most of the other studies, which assess the effects of multi-market contact, evaluate markets that are less concentrated with fewer local markets. In this study the local markets are the 5,974 city-pair routes that are analyzed. Based on prior literature, in markets that that are highly concentrated, it is predicted that the effect of multi-market contact on price dispersion is less. As a result, the increase of price dispersion due to increasing multi-market contact is reduced. The following hypothesis reflects this rationale.

\section{Hypothesis 3: When market concentration is greater, the effect of multi-market contact on price dispersion decreases.}

FIGURE 2 (See Appendix) shows that at high levels of market concentration, multi-market contact has a lesser effect on price dispersion. Notice that the 'high market concentration' is below the 'low market concentration' line. When market concentration in a market is greater ('high market concentration' in the graph), the effect of multi-market contact on price dispersion is less than when market concentration is less ('low market concentration' in the graph), as stated in the hypothesis.

\section{Market Size}

Market size has been measured in several ways, such as the number of customers or sales volume (monetary value or units sold). In this study, market size is the volume of passengers on a city-pair route relative to the most frequently traveled route. In essence, market size measures how many passengers travel on the route, regardless of the number of airlines on the route.

In Borenstein and Rose's (1994) study, market size (referred to as market density) was measured by the total number of flights on the route. They found that in larger markets, there is less price dispersion. This finding is consistent with models of monopolistic competitive price discrimination (Borenstein, 1985; Holmes, 1989) and is hypothesized in this study. The rationale of this finding is that in larger markets there are more customers, who increase the competitive pressure on the airlines, resulting in less 
price dispersion. Borenstein and Rose's (1994) findings support the hypothesis that market size will increase the intensity of rivalry experienced by a firm. These empirical studies and rationale support the following hypothesis:

\section{Hypothesis 4: The size of the local market is negatively related to price dispersion in the local market.}

\section{Route Distance}

Route distance is the linear distance between the cities at each end of the city-pair route. This variable was applied as an independent variable by several researchers (e.g., Borentstein, 1989; Evans \& Kessides, 1994; Hayes \& Ross, 1998) to evaluate pricing related dependent variables. Borentstein (1989) evaluates the importance of route and airport related variables on price levels on airline routes. One of the route variables is route distance and they found route distance to be positively related to the price level on citypair routes. Route distance is applied by Hayes and Ross (1998) to evaluate the causes of price dispersion. Their research finds that dispersion is greater on longer route distances. This leads to the following hypothesis that on longer route distances there tends to be greater price dispersion.

\section{Hypothesis 5: The distance of a city-pair route is positively related to price dispersion on the route.}

\section{Hub Airport}

In 1978, the U.S. Congress enacted the Airline Deregulation Act, which transformed the domestic airline industry from extensive government regulation to a new era of competition (Nannes, 2000). Prior to the Airline Deregulation Act, carriers largely provided point-to point service. Following deregulation, the airlines began to consolidate their operations at specific airports, forming what came to be known as hubs. A "hub" airline combines "local" passengers (i.e., those originating at or destined to the hub) with "connecting" passengers (i.e., those passing through the hub) on the same flight. The approach, referred to as hub-and-spoke, allows "hub" airlines to serve more cities from their hubs (known as spoke routes) and offer greater frequency of service with its aircraft than had been possible with point-to-point service.

Notwithstanding the benefits, the dominance of spoke routes by hub airlines raises concern about the exercise of market power on those routes. Prior research shows that airlines can and do charge higher prices on routes connected to hubs than on non-hub routes where they face more competition. Hub control is a measure of market power (Borenstein, 1989). Borenstein finds that airlines had greater market power in their hubs and as result, price levels were higher and price dispersion was less on routes. In our study, the focus is on price dispersion that occurs on the city-pair route for all of the airlines in the study and not the pricing of individual airlines. Hayes and Ross (1998) apply this variable and find that price dispersion was less in hub airports than in non-hub airports. This leads to the following hypothesis that less price dispersion is expected at hub routes.

\section{Hypothesis 6: When a city-pair route is connected to a hub airport, there is a negative effect on price dispersion on the route.}

\section{RESEARCH METHOD}

The following is a description of the data applied in this study, the empirical model, and the calculation method for the dependent variable, price dispersion measurement:

\section{Data Description}

The data used in this study are from the Origin and Destination Survey of Air Passenger Traffic. The Origin and Destination database consists of a 10\% random sample of all airline passenger tickets issued by all airlines on a quarterly basis for each city-pair route in the U.S. For cities with multiple airports, the 
data are at the airport level. This study focuses on the routes of seven network and ten low-fare airlines during the first quarter of 1999. There are approximately 7,000 city-pair routes in this data set. In this study, only the routes with two or more airlines on a route are included. As a result, 5,974 routes are included in this study.

\section{Empirical Model}

Multiple regression analysis is applied in this study. The following equation is the empirical model for the conceptual model described above.

$$
\begin{aligned}
& P R D_{i j}=\beta_{0}+\beta_{1} M M C_{i j}+\beta_{2} H H I_{i j}+\beta_{3} M M C_{i j} \mathrm{x} H H I_{i j}+\beta_{4} M S Z_{i j}+\beta_{5} D S T_{i j}+\beta_{6} H U B_{i j}+\varepsilon_{i j} \\
& \quad \text { where; } i \text { and } j \text { are the city pairs. } \\
& P R D_{i j}=\text { price dispersion on the city pair route } \\
& M M C_{i j}=\text { multi-market contact among airlines on the city pair route } \\
& H H I_{i j}=\text { market concentration based on airlines on the city pair route } \\
& M S Z_{i j}=\text { market size based on passengers on the city pair route } \\
& D S T_{i j}=\text { route distance between cities on the city pair route } \\
& H U B_{i j}=\text { hub airport based on either terminal being a hub } \\
& \varepsilon_{i j}=\text { error term related to the city pair route }
\end{aligned}
$$

\section{Price Dispersion Measurement - Dependent Variable}

The Gini coefficient measures the degree of inequality of a variable in a distribution of its elements.In our study, price dispersion is based on the variation in airline ticket prices for the same city-pair route offered by competing airlines. Gini is calculated from the average price charged to customers by each airline for each city-pair route per quarter. The Gini coefficient (also referred to as Gini index or Gini ratio) is the most widely used statistical measure of income inequity (Abounoori \& McCloughnan, 2003). The Gini coefficient is an index of inequality, with values closer to unity associated with higher inequality. The Gini coefficient is expressed as (Abounoori \& McCloughan, 2003, p. 505):

$$
G=1-2 \int_{0}^{1} l(z) d z
$$

where $z$ is the cumulative proportion of price payers (i.e., customers) and $l$ is the corresponding cumulative proportion of prices paid.

FIGURE 3 (See Appendix) provides an example of the Gini coefficient measurement of price dispersion. The Gini coefficient is based on comparing the cumulative share of price paid (vertical axis) relative to the cumulative share of passengers (horizontal axis). The curved line is a graphical representation of price dispersion. The area between the curved line and the $45^{\circ}$ is the Gini coefficient; in this case 0.302 . When there is less price dispersion, the Gini coefficient decreases and the price dispersion line approaches the $45^{\circ}$ line. When there is more price dispersion, the Gini coefficient increases and the price dispersion line approaches the lower right corner.

The Gini coefficient is superior in this application to the other measures of inequality mentioned above, due to its inclusion of the measurement of non-normal (and non-uniform) distributions and the potential for calculated values to be continuous, range from zero to one, and ratio data. A value of zero value occurs when these is uniform prices, which means that there is zero price dispersion. The value of zero is referred to as 'perfect equality' and occurs on one route in this data set when there are two airlines with identical average prices. The value of one is referred to as 'perfect inequality' and does not actually occur because it would mean that all passengers except on pays nothing and one passenger pays something. 


\section{INDEPENDENT VARIABLES}

The following is a description of the independent variables applied in this study and the calculation method for each variable.

Multi-market contact is a measure of the potential for strategic market encounters between airlines (Baum \& Korn, 1996). Baum and Korn (1996) develop a methodology for evaluating the level of competition between firms that compete in many different local markets. Baum and Korn's methodology is based on calculating (for only the firms competing in a sub-market) the number of other sub-markets where the firms compete and then divides this number by the maximum number of potential sub-markets where the firms could compete. The range of values for the Baum and Korn's approach to measuring multi-market contact is zero to one. This study applies the Baum and Korn's methodology.

The multi-market contact for firm $i$ in a focal market $m$ is measured using the number of contacts that firm $i$ has with the competitors in market $m$ competing in markets different from focus market mat time $t$ as follows:

$$
\left.\mathrm{MMC}_{\text {int }}=\left[\Sigma_{j \neq i} \Sigma_{m}\left(\mathrm{D}_{\text {imt }} \times \mathrm{D}_{\mathrm{jmt}}\right)\right] /\left[\Sigma_{m} \mathrm{D}_{\mathrm{imt}} \mathrm{x} \mathrm{N}_{\mathrm{MMCt}}\right] \text {, for all } j \Sigma_{m}\left(\mathrm{D}_{\mathrm{imt}} \mathrm{x} \mathrm{D}_{\mathrm{jmt}}\right)\right]>1
$$

where,

$\mathrm{D}_{\text {imt }}$ is an indicator variable set equal to one it firm $i$ is active in a market $m$ at time $t$ and to zero otherwise.

$\mathrm{N}$ is the number of firms $j$ that contact the focal firm $i$ in market $m$ that are multi-market contacts (i.e., that firm $i$ encounters in at least one market other than $m$ ) and all other terms are as defined above.

Multi-market contact can vary from zero, when there is no multi-market contact, to one, when firm $i$ engages all other firms in market $m$ in all of $M$ in its own markets. Given that similar indices have been previously used (e.g., Baum \& Korn, 1996; Gimeno \& Woo, 1996; Fuentelsaz \& Gomez, 2006), this approach to measuring multi-market contact provides the possibility of comparing the results of this study with those of the earlier studies.

Market concentration is the degree of dominance by firms selling similar products within a specific market. Market concentration is typically measured by the Herfindahl index (HHI), which is calculated by squaring the market share for each firm (i.e., airline) competing within a market. In this study, the citypair route is the sub-market of interest and therefore, concentration of airlines is evaluated on each citypair route. The Herfindahl index is calculated using the number of passengers per airline on the city-pair route each quarter.

The Herfindahl index has been applied as an independent variable in many studies including Borenstein and Rose (1994) and Hayes and Ross (1998) to evaluate the causes of price dispersion in the airline industry. The Herfindahl index can vary from near zero, in a market where a very large number of firms compete, all with near zero market shares, to one, when there is only one firm with $100 \%$ market share.

Market size is the number of passengers on a city-pair route. Market size measures how many passengers travel on the route, regardless of the number of airlines on the route. Borenstein and Rose (1994) apply a similar independent variable, based on the total number of flights. In this study, market size is calculated by dividing the number of passengers on the route by the maximum number of passengers on the route 
with the most passengers on a single city-pair route and can vary from near zero, on a route where there are very few passengers, to one, the route with the most passengers.

Route distance is the linear distance between the cities at each end of the city-pair route. Route distances the United States vary from 11 to 2,770 miles. This variable has been applied in a several studies on pricing levels on airline routes (e.g., Borentstein, 1989; Evans \& Kessides, 1994). Hayes and Ross (1998) apply this variable to evaluate causes of price dispersion and scaled route distance by dividing by 1,000 . In this study, the route distance variable is calculated by dividing each city-pair route distance by the longest route distance resulting in values from nearly zero to one.

Hub airport is a zero or one, dichotomous variable, which indicates that an airline's hub is at one or both ends of the city-pair route. If neither endpoint is a hub, the value is zero and if either or both endpoints are hubs, the value is one. Hayes and Ross (1998) apply this variable to evaluate causes of price dispersion. Borenstein (1989) apply this variable and found it to be an indicator of market power.

\section{EMPIRICAL ANALYSIS}

The following sections explain the descriptive statistics, estimation results for the hypotheses, and the model fit.

\section{Descriptive Statistics}

In TABLE 1, the means, standard deviations, and Pearson correlation matrix for the variables of interest are presented. The correlations between the independent variables are relatively small and therefore, multicollinearity is not a concern in this analysis. The largest correlation (0.37) is between market concentration and route distance.

TABLE 1

DESCRIPTIVE STATISTICS $(\mathrm{n}=\mathbf{5 , 9 7 4 )}$

\begin{tabular}{|l|c|c|c|c|c|c|c|}
\cline { 3 - 8 } \multicolumn{2}{c}{} & \multicolumn{6}{c|}{ Correlation Coefficients } \\
\hline Variable & Mean & Std Dev & $\mathbf{1}$ & $\mathbf{2}$ & $\mathbf{3}$ & $\mathbf{4}$ & $\mathbf{5}$ \\
\hline Price Dispersion & 0.059 & 0.0006 & & & & & \\
\hline Multi-Market Contact & 0.248 & 0.0010 & 0.08 & & & & \\
\hline Concentration & 0.458 & 0.0031 & -0.43 & 0.14 & & & \\
\hline Market Size & 0.027 & 0.0008 & -0.13 & -0.29 & 0.01 & & \\
\hline Distance & 0.416 & 0.0031 & 0.32 & 0.10 & -0.37 & -0.09 & \\
\hline Hub Airport & 0.354 & 0.0062 & -0.11 & -0.19 & 0.02 & 0.34 & -0.10 \\
\hline
\end{tabular}

\section{Estimation Results}

The following estimation results are explained for the hypotheses previously discussed and based on the conceptual framework shown in Figure 1. TABLE 2 provides a summary of the regression results. 
TABLE 2

REGRESSION RESULTS

\begin{tabular}{|l|l|l|c|c|c|}
\cline { 2 - 6 } \multicolumn{1}{l|}{} & Variable & Hypothesis & $\begin{array}{c}\text { Coefficient } \\
\text { Estimate }\end{array}$ & Beta & Pr>lt| \\
\hline $\mathrm{H}_{1}$ & $\begin{array}{l}\text { Multi-Market } \\
\text { Contact }\end{array}$ & $\begin{array}{l}\text { Degree of MMC is positively related } \\
\text { to price dispersion. }\end{array}$ & 0.193 & 0.327 & $<0.0001$ \\
\hline $\mathrm{H}_{2}$ & $\begin{array}{l}\text { Market } \\
\text { Concentration }\end{array}$ & $\begin{array}{l}\text { Degree of HHI is negatively related to } \\
\text { price dispersion. }\end{array}$ & -0.029 & -0.127 & 0.0006 \\
\hline $\mathrm{H}_{3}$ & MMC x HHI & $\begin{array}{l}\text { As HHI increases, the effect of MMC } \\
\text { on price dispersion decreases. }\end{array}$ & -0.236 & -0.377 & $<0.0001$ \\
\hline $\mathrm{H}_{4}$ & Market Size & $\begin{array}{l}\text { Market size is negatively related to } \\
\text { price dispersion. }\end{array}$ & -0.053 & -0.073 & $<0.0001$ \\
\hline $\mathrm{H}_{5}$ & Route Distance & $\begin{array}{l}\text { Length of the route is positively } \\
\text { related to price dispersion. }\end{array}$ & 0.033 & 0.164 & $<0.0001$ \\
\hline $\mathrm{H}_{6}$ & Hub Airport & $\begin{array}{l}\text { When a route is connected to a hub, } \\
\text { there is a negative effect on price } \\
\text { dispersion. }\end{array}$ & -0.004 & -0.044 & 0.0002 \\
\hline
\end{tabular}

\section{Multi-Market Contact}

$\mathrm{H}_{1}$ is supported $\left(\beta_{1}=0.327\right)$, indicating that in city-pair routes where multi-market contact is greater, there is more price dispersion. In other words, when competitors in a local market have more contact in markets, the price dispersion tends to be greater in the local market. This finding is consistent with the research of Baum and Korn (1996), which found that in local markets where multi-market contact is greater, the entry and exit rates are lower, indicating a reduction in competitiveness. This study supports the premise that if firms feel less need to compete aggressively, they have more latitude in pricing, therefore in local markets where multi-market contact is greater, there is larger price dispersion.

The beta coefficient of multi-market contact is relatively large (0.317) compared to all but one of the other beta values, which range from 0.044 to 0.377 . This relatively large value indicates that multi-market contact is a key variable in influencing the dependent variable, price dispersion. Multi-market contact has the coefficient estimate of 0.193 , which is the highest of the main effect variables and is only second to the interaction variable that has a coefficient estimate of -0.236 . This result supports the multi-market contact theory, which postulates that as the degree of multi-market contact increases, price dispersion should increase. This finding demonstrates the considerable positive effect that multi-market contact has on price dispersion.

\section{Market Concentration}

$\mathrm{H}_{2}$ is supported $\left(\beta_{2}=-0.127\right)$, indicating that in local markets where concentration is greater, price dispersion in that market tends to be less. In other words, in markets where market shares are more concentrated, less price dispersion occurs. These results are consistent with Borenstein and Rose's (1994) study on price dispersion in the U.S. airfare market. They analyzed pricing data to evaluate the effect of competition on price dispersion. Market concentration is one of the variables used by Borenstein and Rose to evaluate the construct 'competition'. Borenstein and Rose found that in local markets where market concentration is higher, there is less price dispersion. Market concentration is also applied by Hayes and Ross (1998), Walsh and Whelan (1999), and Zhao (2006) to evaluate the causes of price 
dispersion. Their findings reinforce the finding that in more concentrated markets, price dispersion tends to be less.

Market concentration has the coefficient estimate of -0.029 , which is relatively small compared to multi-market contact, but still has a significant negative influence on price dispersion. This result supports the oligopoly theory, which postulates that firms collude, either tacitly or purposively, within markets when they recognize their mutual dependence. The more concentrated the market, the greater recognition of the firms' mutual dependence, resulting in less price dispersion. This rationale is consistent with the finding of this study that as concentration in a local market increases, there tends to be less price dispersion. For example, if market concentration on a city-pair route increases from 0.25 to 0.30 (a $20 \%$ increase in market concentration) price dispersion can be expected to decrease from 0.040 to 0.038 (a 5\% decrease in price dispersion). In comparison to multi-market contact, market concentration has less effect on price dispersion.

\section{Interaction of Multi-Market Contact and Market Concentration}

$\mathrm{H}_{3}$ is supported $\left(\beta_{3}=-0.377\right)$, indicating that the effect of multi-market contact on price dispersion is less in local markets where there is greater market concentration. In other words, in local markets where there is a higher degree of market concentration, the increase in price dispersion (that occurs as multimarket contact increases) is less than it would be in less concentrated markets. This finding is consistent with prior literature which indicates that in markets where concentration is greater, the effect of multimarket contact on price dispersion is reduced, and as a result there is less of an increase in price dispersion. This finding demonstrates that even though multi-market competition reduces competitive pressure, when markets are highly concentrated, there are relatively few firms setting prices, which has a reducing effect on price dispersion.

\section{Market Size}

$\mathrm{H}_{4}$ is supported $\left(\beta_{4}=-0.073\right)$, indicating that in larger local markets, price dispersion in that market tends to be less. In other words, in larger markets (i.e., more customers), less price dispersion occurs. Market size has the coefficient estimate of -0.053 , which is the second highest of the main effect variables. This finding is consistent with Borenstein and Rose's (1994) study, which found that in larger markets, there is less price dispersion. Their findings support the rationale that in larger markets (i.e., more customers) there is more competitive pressure on the airlines, resulting in less price dispersion. Furthermore, the finding of this study is consistent with models of monopolistic competitive price discrimination (Borenstein, 1985; Holmes, 1989). For example, if market size on a city-pair route increases from 0.25 to 0.30 ( $20 \%$ increase in market size) price dispersion can be expected to decrease from 0.024 to 0.031 ( $8 \%$ decrease in price dispersion). In comparison to multi-market contact, market size has less effect on price dispersion, but more than market concentration.

\section{Route Distance}

$\mathrm{H}_{5}$ is supported $\left(\beta_{5}=0.164\right)$, indicating that as route distance increases, there is greater price dispersion. In other words, longer routes tend to have more price dispersion than shorter routes. Route distance has the coefficient estimate of 0.033 , which is the third highest of the main effect variables. The rationale behind this finding is that on longer routes, there tends to be less competition, which reduces the competitive pressure to compete on price. Furthermore, some passengers prefer more services on longer distance flights due to the longer times that they spend in the airplane, which leads to less price sensitivity and more price dispersion. The finding of this study is consistent with prior research of Hayes and Ross (1998) who found that dispersion increases on longer route distances. For example, if route distance on a city-pair route increases from 0.25 to 0.30 (20\% increase in route distance) price dispersion can be expected to decrease from 0.055 to 0.057 ( $3 \%$ increase in price dispersion). In comparison to multimarket contact, route distance has much less effect on price dispersion. 


\section{Hub Airport}

$\mathrm{H}_{6}$ is supported $\left(\beta_{6}=-0.044\right)$, indicating that when the city-pair route is connected to an airport that is a hub for at least one airline (other than a focal airline), price dispersion on that route tends to be less. In other words, in a local market where there is a dominant, local firm, (but not dominant nationally) less price dispersion occurs. This finding is consistent with prior research of Hayes and Ross (1998) who found that dispersion was less in routes connected to hub airports than in routes connected to non-hub airports. Hub airport has the coefficient estimate of -0.004 , which is the third highest of the main effect variables, which is the smallest of all the coefficients, but still has a significant influence on price dispersion. For example, if at least one of the airports on a city-pair route becomes a hub (the 'hub airport' variable changes from 0 to 1), price dispersion can be expected to decrease from 0.047 to 0.043 ( $9 \%$ decrease in price dispersion). In comparison to a $10 \%$ increase in multi-market contact, if at least one of the airports on a city-pair route becomes a hub, the magnitude of the effect of the hub airport is similar, but opposite in direction of a $10 \%$ increase in multi-market contact's effect on price dispersion.

\section{Model Fit}

One of the key objectives of this research is to evaluate and demonstrate the benefit of including an evaluation of the macro competitive environment (i.e., multi-market contact) on price dispersion in local markets. TABLE 3 provides the comparison of the results from the models discussed. When market concentration is applied exclusively to explain price dispersion, the adjusted $\mathrm{R}^{2}$ value is 0.182 , meaning that market concentration explains $18.2 \%$ of the variation in price dispersion. By including multi-market contact and the interaction of concentration and multi-market contact, $20.9 \%$ of the variation is explained and with the full model, $24.2 \%$ is explained. The increase in adjusted $\mathrm{R}^{2}$ from 0.182 to 0.242 is a $33 \%$ increase in adjusted $\mathrm{R}^{2}$ and demonstrates the value of considering multi-market contact and local market conditions when evaluating price dispersion.

TABLE 3

\section{COMPARISON OF RESULTS}

\begin{tabular}{|l|c|c|c|}
\hline Condition & Adjusted $\mathbf{R}^{\mathbf{2}}$ & $\begin{array}{c}\text { Change in } \\
\text { Adjusted } \mathbf{R}^{\mathbf{2}}\end{array}$ & Percent Improvement \\
\hline $\begin{array}{l}\text { Market concentration } \\
\text { alone }\end{array}$ & 0.182 & ---- & ---- \\
\hline $\begin{array}{l}\text { Multi-market contact } \\
\text { with market } \\
\text { concentration and } \\
\text { interaction (MMC x } \\
\text { HHI) }\end{array}$ & 0.209 & 0.027 & $15 \%$ \\
\hline Full model & 0.242 & 0.060 & $33 \%$ \\
\hline
\end{tabular}

\section{CONCLUSIONS AND IMPLICATIONS}

The purpose of this empirical study has been to comprehensively evaluate the effects of several key competition related factors, especially multi-market contact, on price dispersion in the airline industry. This study supports the concept that firms respond to competition by searching for alternative ways to improve their performance. One of our research goals is to increase the understanding of the effect of multi-market contact on price dispersion. Prior research has not included multi-market contact to evaluate price dispersion. The results show the importance of including multi-market contact and other key market characteristics in models that addresses competition within markets. 
The conceptual framework developed in this article makes a significant contribution to the understanding of the competitive determinants on price dispersion in a complex, service market. The results have the potential for application in other fixed capacity, service applications, such as entertainment (including sporting event venues), other forms of public transportation (e.g., trains, buses, and ships), and distribution of energy (e.g., electricity). This study expands the understanding of competition theory that may be useful to academic researchers and marketing practitioners. Also, the findings provide information that may be useful in the development of future government policies related to competition's effect on market efficiency and social welfare.

\section{Theoretical Implications}

The findings of this empirical analysis have important theoretical implications. The most significant academic contribution of this study is the development of a conceptual framework of the competitive determinants of price dispersion, including multi-market contact, in a complex service market context. The moderating effect of market concentration on multi-market contact has price dispersion has useful implications for pricing research. Linked oligopoly theory (Solomon, 1970) suggests that the degree of linkage between the firms in multiple markets is an imperative determinant of performance in an oligopolistic market. This theory assumes that multi-market firms coordinate their operations across markets and that this coordination affects the intensity of rivalry. In this study, the interaction of multimarket contact and market concentration has the highest coefficient estimate $(-0.236)$ and beta $(0.377)$ of any variable in the model. This result demonstrates that increasing market concentration dampens the effect that multi-market contact has on price dispersion. Therefore, if price dispersion is desirable in order to increase social welfare and improve industry performance, less market concentration is beneficial.

An additional theoretical implication is the extension of multi-market competition theory to price dispersion. This theory suggests that when two rival firms compete in multiple markets, intensity of rivalry decreases due to mutual forbearance (Bernheim \& Whinston, 1990; Baum \& Korn, 1996; Jayachandran, Gimeno, \& Varadarajan, 1999). This decrease in rivalry results in greater price dispersion due to firms feeling less pressure to match or be close to competitors' prices. This study shows that multimarket contact has a significant influence on price dispersion. Multi-market contact has the highest coefficient estimate $(0.193)$ and beta $(0.327)$ of the main effect variables. This result supports the theory by demonstrating that as the degree of multi-market contact increases, price dispersion tends to increase.

\section{Managerial Implications}

Airlines, as well as other fixed capacity, service organizations, are seeking information to help them improve the financial performance of their organizations. This study has several useful and valuable implications for managers. The information presented can be useful to marketing managers in developing pricing strategies by helping them better understand likely competitive reactions to changes in market structure. This information about the effects of competition on price dispersion applies to managers working for firms that are considering entering new markets. Also, the information can be useful to mangers of rival firms working in the local market when a rival firm enters the local market.

Managers can apply this framework on price dispersion is number of ways. The following are a few key opportunities:

1. Evaluating the effect of strategic moves (e.g., pricing strategies, market entry and exit) on local market price dispersion).

2. Improving the evaluation of local market attractiveness before firms enter new, local markets; revenue potential and profit potential are important considerations. Price dispersion has an important influence on revenue and profitability.

3. Predicting how rival firms, who they compete against in other markets, may affect the price dispersion in the local markets, if their firm or a rival firm enters the local market.

Managers have the means to measure all of the independent variables in this study. By measuring and evaluating these variables, the model developed in this study predicts the effect of competition on price 
dispersion. The findings suggest that managers can benefit from monitoring and assessing multi-market contact and market concentration in local markets when making pricing decisions. A better understanding of the factors (i.e., multi-market contact, market concentration) that cause price dispersion to expand or contract provides important and useful information to managers developing pricing strategies and setting prices.

\section{Future Research}

Several implications and direction for future research can be drawn from the results of this study, as well as from some of the limitations. First, since the findings of this study are based on firms in a single, geographically bounded industry during one quarter, it is possible that the results reflect some factors specific to the industry, geographic region, or period under study. Further replications of this study in other circumstances are needed to address this possibility.

Second, development of a comprehensive variable for strategic competitive heterogeneity that may include multi-market contact and strategic similarity is worth exploring. One of the fundamental issues is to determine what characteristics of firms set them apart from competitors in ways that affect their marketing strategies and how consumers perceive value of their product offerings. When firms can increase the perceived value of their product offerings, they can increase sales revenue, profitability relative to other firms with less attractive products. Findings of this research show that multi-market contact in conjunction with market concentration improves the potential for firms to increase their financial performance in the marketplace.

\section{REFERENCES}

Abounoori, E., \& McCloughan., P. (2003). A Simple Way to Calculate the Gini Coefficient for Grouped as Well as Ungrouped Data. Applied Economic Letters, 10, 505-509.

Baum J. A. C., \& Korn, H. J. (1996). Competitive Dynamics of Interfirm Rivalry. Academy of Management Journal, 39, (2), 255-291.

Bernheim, D., \& Whinston, M. D. (1990). Multimarket Contact and Collusive Behavior. Rand Journal of Economics, 21, 1-26.

Biswas, A., Dutta, S., \& Pullig, C. (2006). Low Price Guarantees as Signal of Lowest Price: The Moderating Role of Perceived Price Dispersion. Journal of Retailing, 82, (3), 245-257.

Borenstein, S., \& Rose N. L. (1994). Competition and price dispersion in the U.S. Airline Industry. Journal of Political Economy, 102, (4), 653-683.

Borenstein, S. (1989). Hubs and High Fares: Dominance and Market Power in the U.S. Airline Industry. Rand Journal of Economics, 20, 344-365.

Borenstein, S. (1985). Price Discrimination in Free-Entry Market. Rand Journal of Economics, 16, 380397.

Chen, P. Y. \& Hitt, L. M. (2001). Brand Awareness and Price Dispersion in Electronic Markets. $22^{\text {nd }}$ Annual International Conference on Information Systems, 233-246.

Clemons, E. K., Hann I. H., \& Hitt, L. M. (2002). Price Dispersion and Differentiation in Online Travel: An Empirical Investigation. Management Science, 48, 534-549. 
Evans, W. N., \& Kessides, I. N. (1994). Living by the Golden Rule: Multimarket Contact in the U.S. Airline Industry. The Quarterly Journal of Economics, 109, (2), 341-366.

Feinberg, R. M. (1984). Mutual Forbearance as an Extension of Oligopoly Theory. Journal of Economics and Business, 36, 243-249.

Dixit, A. Whipple, T. W., Zinkham, G. M., \& Gailey, E. (2008). A Taxonomy of Information Technology-Enhanced Pricing Strategies. Journal of Business Research, 61, 275-283.

Gimeno, J. \& Woo, C. Y. (1996). Hypercompetition in a Multimarket Environment: The Role of Strategic Similarity and Multimarket Contact in Competitive De-Escalation. Organization Science, 7, 322-341.

Grewal, D., \& Marmorstein, H. (1994). Market Price Variation and Consumers' Price Search Decisions for Durable Goods. Journal of Consumer Research, 21, (3), 453-460.

Hayes, K. J., \& Ross, L. B. (1998). Is Airline Price Dispersion the Result of Careful Planning of Competitive Forces? Review of Industrial Organization, 13, 523-541.

Holmes, T. J. (1989). The Effects of Third-Degree Price Discrimination in Oligopoly. American Economic Review, 79, (1), 244-250.

Jayachandran, S., Gimeno J, \& Varadarajan, P. R. (1999). The Theory of Multimarket Competition: A Synthesis and Implications of Marketing Strategy. Journal of Marketing, 63, 49-66.

Johnson, E. J., Moe, W. W., Fader, P. S., Bellman S., \& Lohse, G. (2004). On the Depth and Dynamics of Online Search Behavior. Management Science, 50, (3), 299-308.

Karnani, A., \& Wernerfelt, B. (1985). Multiple Point Competition. Strategic Management Journal, 6, (1), $87-96$.

Lindsey-Mullikin, J., \& Grewal, D. (2006). Imperfect Information: The Persistence of Price Dispersion on the Web. Journal of Marketing Science, 34, (2), 236-243.

Nannes, J. M. (2000). Statement Before the Committee of the Judiciary U.S. House of Representatives Concerning Airline Hubs and Mergers. Department of Justice, Retrieved April 24, 2007 from http://www.usdoj.gov'atr/public/testimony/4956.htm.

Pan, X., Ratchford B. T., \& Shankar, V. (2004). Can Price Dispersion in Online Markets Be Explained by Differences in e-Tailer Service Quality? Journal of the Academy of Marketing Science, 30, (4), 433-445.

Solomon, E. H. (1970). Bank Merger Policy and Problems: A Linkage Theory of Oligopoly. Journal of Money, Credit, and Banking, 2, (3), 323-336.

Stigler, G. J. (1961).The Economies of Information. Journal of Political Economy, 69, 213-225.

Tellis, G. J. (1986). Beyond the Many Faces of Price: An Investigation of Pricing Strategies. Journal of Marketing, 50, (4), 146-160.

Walsh, P. P., \& Whelan, C. (1999). Modeling Price Dispersion as an Outcome of Competition in the Irish Grocery Market. Journal of Industrial Economics, 47, (3), 325-343. 
Zhao, Y. (2006). Price Dispersion in the Grocery Market. Journal of Business, 79, (3), 1175-1191.

\section{APPENDIX}

FIGURE 1

CONCEPTUAL FRAMEWORK OF PRICE DISPERSION

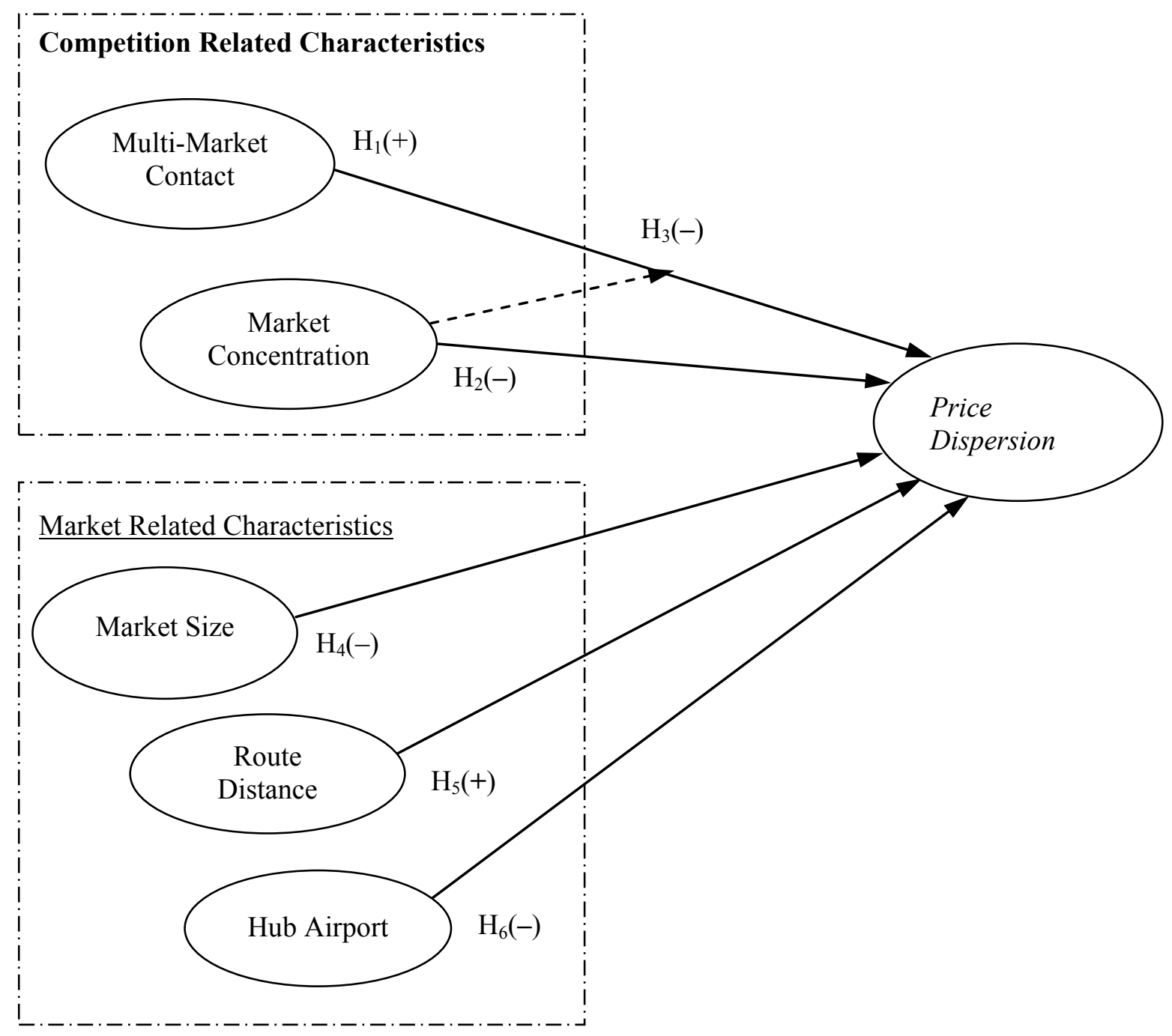

Note: Dotted line indicates interaction between variables. 
FIGURE 2

INTERACTION EFFECT BETWEEN MMC AND MARKET CONCENTRATION

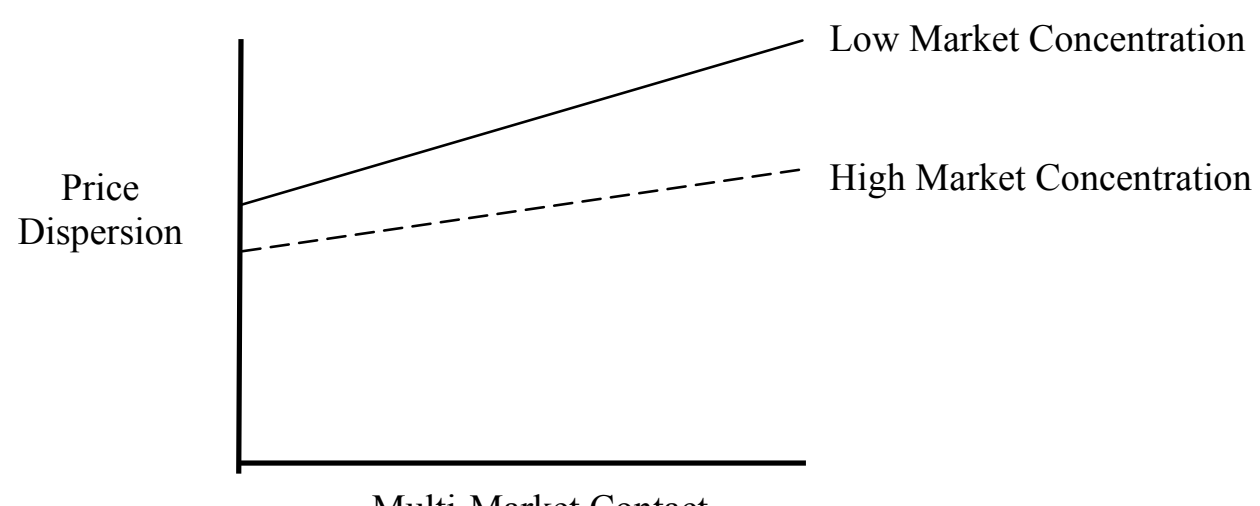

FIGURE 3

GINI COEFFICIENT

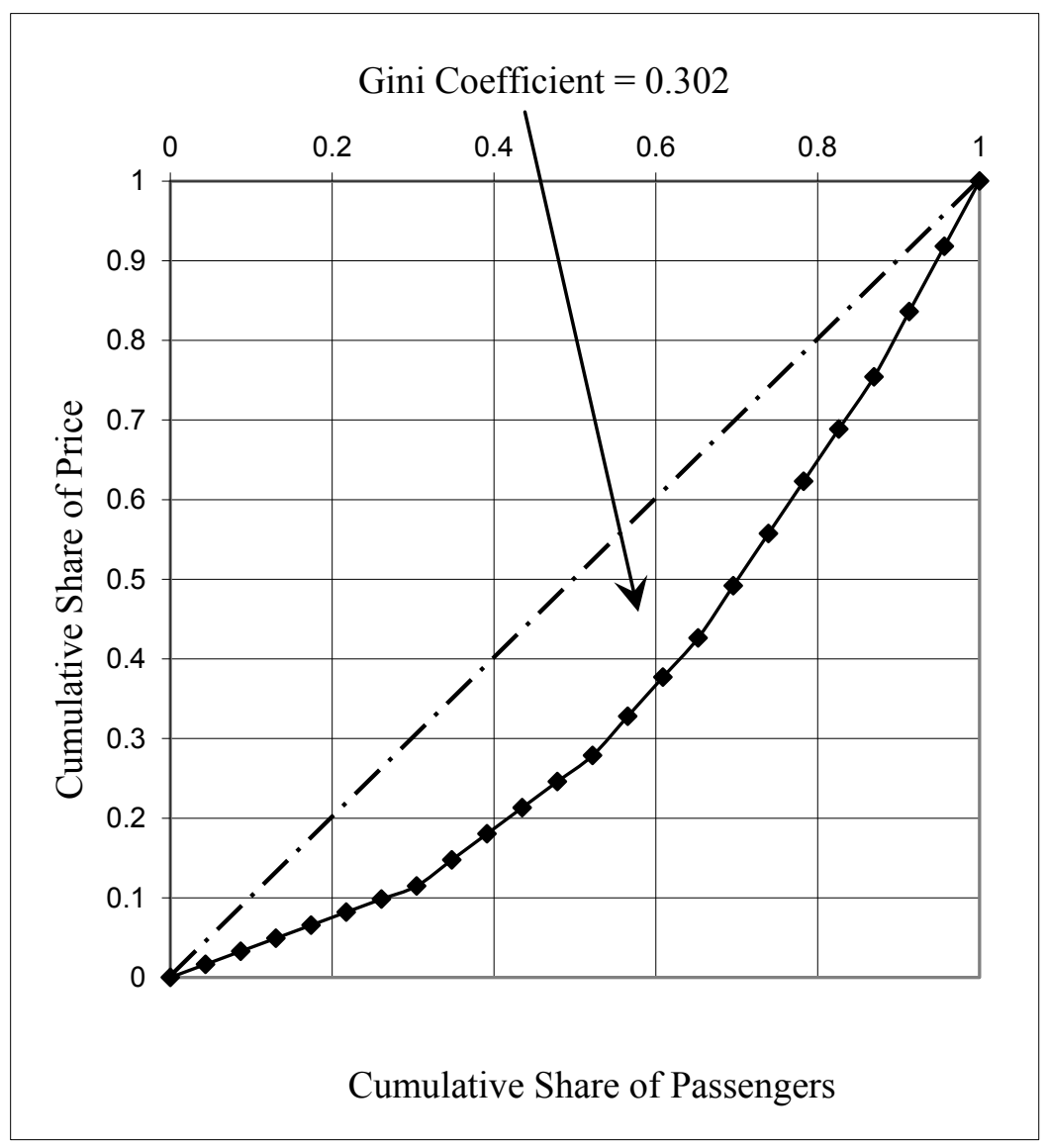

